\title{
IMPLEMENTASI PROGRAM KAMPUNG KB SEBAGAI INOVASI STRATEGIS PENCEGAHAN 4T (4 TERLALU) DALAM KEHAMILAN DI RW 10 MARGADANA, TEGAL
}

\author{
Seventina Nurul Hidayah ${ }^{1}$, Ulfatul Latifah ${ }^{2)}$ \\ E-mail address: seventinanurulhidayah@gmail.com
}

\begin{abstract}
Today many women do not know when is the right time to start getting pregnant and cannot be pregnant again. The situation is too 4 (young, old, close and many) to be an internal factor of the mother which affects the complications of pregnancy and childbirth which have an impact on AKI and AKB. This research was based on the declaration of a KB village in RW 10 Margadana Village. The purpose of this study is to analyze the implementation of the KB Village program in RW 10 Margadana Village.

This research is qualitative using descriptive method. Data collection was carried out by in-depth interview techniques in accordance with interview guidelines. The results of interviews were recorded and made field notes with a research model using a model on Public Policy Implementation developed by George C. Edward III.

The results of the research showed that from four indicators of the program, two of them have been achieved well, namely disposition and bureaucracy structure, this was because in the implementation of the program of Kampung KB, the program executor and the target were already maximum. Yet the indicators of resources have not met the requirements because of the inadequate facilities. Among the obstacles in the implementation of Kampung $\mathrm{KB}$ program were communication from the local government cannot unite related agencies, namely the population and health services, insufficient budgets and the lack of participation and awareness of the community in RW 10 Margadana village. The researcher recommended suggestions: the posts of Kampung $\mathrm{KB}$ are to be made specifically for activities related to family planning,, and in the socialization, the BKKBN (National Population and Family Planning Board) Lampung should motivate the community to participate in the implementation of Kampung KB program in RW 10 Margadana Village.
\end{abstract}

Keywords: Policy; Kampung KB Program; 4T in pregnancy

1) 2) Politeknik Harapan Bersama Tegal

\section{Pendahuluan}

ASI merupakan terbaik bagi bayi yang Menurut data BKKBN Provinsi Jawa Tengah (2012), Kampung Keluarga Berencana (KB) merupakan suatu upaya yang merupakan gagasan presiden Jokowi yang memiliki makna sebagai pembangunan nasional yang difokuskan untuk pengembangan yang berawal dari tingkat paling rendah yaitu desa atau kampung. Kampung $\mathrm{KB}$ juga dirancang sebagai upaya pendekatan akses pelayanan Keluarga Berencana kepada keluarga kecil di 
desa atau kampung dalam aktualisasi 8 fungsi keluarga. Kampung KB dibangun berada pada tingkat RW atau dusun dengan menggunakan pendekatan budaya masing-masing daerah dengan tujuan utama untuk meningkatkan kualitas hidup masyarakat ditingkat kampung atau yang setara melalui program kependudukan, keluarga berencana dan pembangunan keluarga, pembangunan sektor dalam rangka mewujudkan keluarga kecil yang berkualitas serta meningkatkan jumlah peserta KB aktif MKJP.

Pembentukan Kampung KB di Kota Tegal menunjukkan adanya partisipasi masyarakat pada program KB yang dipilih dan ditetapkan melalui Surat Keputusan Wali Kota Tegal yang didukung oleh lintas sektor dan seluruh OPD Pemerintah Kota Tegal sehingga Kampung $\mathrm{KB}$ tersebut tidak hanya membangun program KKBPK juga berbagai fasilitas mulai dari jalan, rumah tidak layak huni, sosial, ekonomi, budaya, pendidikan dan lainnya. Menurut data BKKBN Kota Tegal tahun 2016, Kampung KB yang telah terbentuk di wilayah kota Tegal yaitu di RW 10 Kelurahan Panggung Kecamatan Tegal Timur, Kampung KB di RW 04 Kelurahan Kalinyamat Wetan Kecamatan Tegal Selatan, RW 02 Kelurahan Muarareja Kecamatan Tegal Barat, RW 05 Kelurahan Slerok Kecamatan Tegal Timur dan RW 10 Kelurahan Margadana Kecamatan Margadana.
Margadana merupakan salah satu kelurahan di wilayah Kota Tegal. Berdasarkan data hasil penelitian di Kelurahan Margadana Tahun 2015 terdapat $1.940 \mathrm{ibu}$ hamil dan ibu hamil yang mendapatkan pemeriksaan sejumlah $1.554 \quad(80 \%)$ sedangkan yang belum mendapatkan pelayanan sejumlah 386 (20\%).

Jumlah kehamilan di Kelurahan Margadana menduduki peringkat terbanyak dibandingkan kelurahan yang lain dengan jumlah kehamilan terkontrol $100 \%$ dari jumlah kehamilan (tabel 1)

Tabel 1. Data Ibu Hamil di Kecamatan Margadana Tahun 2015

\begin{tabular}{clcc}
\hline N & Kelurahan & $\begin{array}{c}\text { Jumlah } \\
\text { Kehamilan }\end{array}$ & $\begin{array}{c}\text { Jumlah } \\
\text { Kehamilan } \\
\text { Terkontrol }\end{array}$ \\
\hline 1 & Kaligangsa & 76 & 76 \\
2 & Krandon & 237 & 237 \\
3 & Cabawan & 38 & 38 \\
4 & Margadana & 654 & 654 \\
5 & Kalinyamat & 467 & 111 \\
& Kulon & & 424 \\
6 & Sumur & 424 & 14 \\
& Panggang & & \\
7 & Pesurungan & 44 & 1554 \\
\hline & Lor & 1940 &
\end{tabular}

Sumber : Laporan Pelaksanaan Kegiatan PKK Tahun 2015

Kehamilan adalah dambaan semua perempuan, juga termasuk suami dan anggota keluarga lainnya. Melalui kehamilan, ibu, suami dan kelaurga mendapatkan generasi penerus yang bisa menjadi sumber kebahagiaan dalam kehidupan. Namun, terdapat kondisi dimana ibu hamil 
menjadi beresiko tinggi, yaitu suatu kehamilan dimana kesehatan ibu dan bayi dalam kandungan bisa terancam sewaktu-waktu. Kondisi yang dapat menyebabkan kehamilan menjadi beresiko adalah 4T (4 Terlalu) dalam kehamilan. Menurut data Kemenkes (2011) terdapat sekitar $65 \%$ ibu hamil yang mengalami salah satu atau lebih dari kriteria 4 T. Kondisi ini bisa meningkatkan resiko terjadinya komplikasi bagi bayi dan ibu pada saat hamil dan melahirkan. Menurut ahli kesehatan Ibu dan Anak (Novi Maharani) langkah BKKBN mencanangkan program kampung $\mathrm{KB}$ yang merupakan perwujudan dari Nawacita pembangunan manusia, yakni membangun Indonesia dari pinggiran dengan memperkuat daerah dan desa dalam kerangka NKRI, dan meningkatkan kualitas manusia itu sendiri.

Program Kampung KB bertujuan untuk memberikan jarak dan menjarangkan kehamilan dan bermanfaat untuk menjaga kesehatan fisik dan psikologi ibu dan anak sebelumnya. Manfaat lainnya yaitu mampu menjaga hubungan antara anak dan ibu yang dalam jangka panjang akan berpengaruh pada kualitas SDM. Selain itu, program tersebut juga akan memberikan waktu yang cukup bagi ayah untuk mempersiapkan kebutuhan secara ekonomi.Tanpa program KB, maka laju pertumbuhan penduduk tidak akan terkendali. Dampak lainnya, akan terjadi peningkatan kehamilan resiko tinggi. Misalnya, kehamilan jarak terlalu dekat, kehamilan usia lanjut, dan kehamilan usia remaja. Merujuk data resmi, 5-10 persen dari kehamilan termasuk kehamilan dengan resiko tinggi.

\section{Metode Penelitian}

Penelitian dilakukan di rumah responden yaitu 2 Pasangan Usia Subur yang tinggal di RW 10 Kelurahan Margadana Kota Tegal. Penelitian ini bersifat kualitatif dengan menggunakan metode deskriptif. Sampel diambil secara purposive sampling, yang disesuaikan dengan tujuan dan jenis penelitian.

Sampel pada penelitian ini adalah informan utama dan informan triangulasi. Sebagai informan utama dalam penelitian ini adalah masyarakat yaitu 2 Pasangan Usia Subur yang berkaitan dengan fokus penelitian dan sebagai informan triangulasi nya adalah Badan Kependudukan Keluarga Berencana Nasional (BKKBN), PLKB Kampung KB, Lurah/sekretaris lurah Margadana. Dalam penelitian ini jumlah sampel ditentukan oleh tersaturasinya sumber informan.

Pengumpulan data dilakukan dengan teknik wawancara mendalam sesuai dengan pedoman wawancara. Hasil wawancara direkam dan dibuat catatan lapangan.Untuk menghindari subyektifitas, peneliti menggunakan teknik triangulasi sumber. 


\section{Hasil dan Pembahasan}

\section{A. Sumber Daya}

Menurut George Edward III sumber daya benar-benar signifikan terhadap proses implementasi kebijakan. Sumber daya meliputi sumber daya fisik (fasilitas), sumberdaya staf (jumlah dan kompetensinya), sumberdaya informasi dan sumberdaya kewenangan (Authority). Menurut Van Meter dan Van Horn, sumber daya lain yang tidak kalah pentingnya lagi adalah sumberdaya finansial (dana) dalam jumlah yang mencukupi dan ketepatan dalam mengalokasikannya serta sumber daya waktu.

Dikaitkan dengan penelitian ini, peneliti akan mengambil beberapa pendapat dari Edward III dan Van Meter dan Van Horn kemudian menggabungkannya. Dalam implementasi program Kampung KB, sumber daya yang dapat digunakan yakni, sumber daya staf baik dilihat dari jumlah maupun kompetensinya; sumber daya fisik (fasilitas); sumberdaya finansial (dana). Berikut ini merupakan tabel data yang akan menjelaskan mengenai faktor sumber dalam implementasi program Kampung KB di RW 10 Margadana :

Tabel 2. Rekapitulasi hasil wawancara dalam implementasi Program Kampung KB di RW 10 Kelurahan Margadana

\begin{tabular}{lll}
\hline Indikator & $\begin{array}{l}\text { Implementasi } \\
\text { Jampersal }\end{array}$ & Dampak \\
\hline $\begin{array}{l}\text { Sumber } \\
\text { Daya Staf }\end{array}$ & Sudah cukup & $\begin{array}{l}\text { Mampu } \\
\text { memberikan } \\
\text { pelayanan yang } \\
\text { berkualitas }\end{array}$ \\
\hline Sumber & Sudah & $\begin{array}{l}\text { Mampu untuk } \\
\text { memenuhi }\end{array}$ \\
\hline
\end{tabular}

\begin{tabular}{lll}
\hline pendanaan & mencukupi & $\begin{array}{l}\text { kebutuhan } \\
\text { pendanaan } \\
\text { dalam program } \\
\text { kampung KB }\end{array}$ \\
\hline $\begin{array}{l}\text { Sumber } \\
\text { daya dan } \\
\text { fasilitas }\end{array}$ & $\begin{array}{l}\text { Sudah } \\
\text { memadai }\end{array}$ & $\begin{array}{l}\text { Memperlancar } \\
\text { dan }\end{array}$ \\
& kuantitas dan & $\begin{array}{l}\text { mempercepat } \\
\text { proses kegiatan } \\
\text { kampung KB }\end{array}$
\end{tabular}

Sumber : Hasil pengolahan data

Berdasarkan data di atas, dapat diketahui bahwa terdapat tiga aspek sumber daya yang berperan dalam implementasi program kampong KB di RW 10 Kelurahan Margadana yang terdiri dari sumber daya petugas pelaksana, sumber daya pendanaan dan sumber daya fasilitas. Untuk sumber daya staf, jika dilihat dari segi kuantitas atau jumlah maupun kualitas dari petugas pelaksana cukup memenuhi. Wilayah margadana memiliki jumlah akseptor $\mathrm{KB}$ yang cukup tinggi namun hal tersebut dapat ditangani dengan baik oleh pihak petugasyang bertugas dalam mensuksekan program Kampung KB di RW 10 Margadana. Keberadaan Kampung KB sangat efektif membantu akseptor KB yang ingin mendapatkan informasi terkait upaya menjarangkan kehamilan untuk mencapai keluarga yang berkualitas, sehingga mereka bisa segera mendapatkan pelayanan yang cepat dan tepat. Jumlah staf pelaksana yang mencukupi tersebut juga didukung oleh kompetensi dan kemampuan yang cukup memadai. Para staf memiliki tingkat pendidikan yang sesuai dengan bidang pekerjaannya masing-masing, memiliki keahlian dan kemampuan guna mendukung dan menunjang tugasnya dalam pelaksanaan program kampong $\mathrm{KB}$ tersebut 
Untuk sumberdaya pendanaan pelaksanaan program kampung $\mathrm{KB}$ berasal dari DIPA provinsi Jawa Tengah dan APBD Kota Tegal. Dalam program Kampung KB warga diberikan motivasi untuk menggunakan KB dengan MKJP (Metode Kontrasepsi Jangka Panjang). Komunikasi yang dilakukan petugas tentunya sudah cukup maksimal, karena pengenalan program Kampung KB kepada masyarakat dilakukan melalui sosialisasi atau penyuluhan yang diadakan secara menyeluruh untuk memberikan pengetahuan dan pemahaman secara jelas dan mengenai pelaksanaan program kampong $\mathrm{KB}$ melalui kegiatan warga seperti di pengajian, posyandu, dan kegiatan lainnya. Sehingga, diperlukan sebuah komunikasi atau sosialisasi secara menyeluruh terhadap masyarakat di wilayah RW 10 Kelurahan Margadana guna memperluas pengetahuan dan pemahaman masyarakat mengenai pelaksanaan program Kampung KB.

\section{Struktur Birokrasi dalam implementasi program Kampung KB}

Struktur organisasi merupakan bagian yang bertugas untuk mengimplementasikan kebijakan. Salah satu dari aspek struktur yang penting dari setiap organisasi adalah adanya prosedur operasi yang standar (SOP). Dengan menggunakan SOP, para pelaksana dapat mengoptimalkan waktu yang tersedia dan dapat berfungsi untuk menyeragamkan tindakan-tindakan pejabat dalam organisasi yang kompleks dan tersebar luas, sehingga dapat menimbulkan fleksibilitas yang besar dan kesamaan yang besar dalam penerapan peraturan (Thoha, 2013)

SOP menggunakan juknis Kampung KB sebagai pedoman prosedur pelaksanaan kampung $\mathrm{KB}$ serta fragmentasi yang mana pembagian tugas yang dijalankan oleh Dinas PPKBD, UPT-PPKBD, PLKB dan kader sudah sesuai dengan harapan. Struktur birokrasi dalam implementasi program kampung KB di RW 10 Margadana melibatkan beberapa elemen atau bagian organisasi pelaksana program. Setiap bagian dari pelaksana tersebut memiliki fungsi dan tugas yang berbeda sesuai dengan pedoman dan petunjuk pelaksanaan program Jampersal yang telah ditetapkan. Perbedaan fungsi dan tugas di antara berbagai elemen pelaksana tersebut diintegrasikan ke dalam suatu koordinasi yang dilakukan secara jelas, efektif dan efisien. Koordinasi tersebut diperlukan untuk menciptakan kondisi kerja sama yang baik dan selaras antara berbagai pihak pelaksana program Jampersal sehingga pelaksanaan program Jampersal dapat berjalan mengarah kepada tujuan yang ingin dicapai.

\section{Komunikasi dalam implementasi program Kampung KB}

Komunikasi memiliki peran penting bagi berlangsungnya koordinasi dalam implementasi suatu kebijakan. Komunikasi merupakan proses koordinasi dan integrasi dari berbagai fungsi yang ada dalam setiap bagian dari struktur pelaksanaan kebijakan guna mendapatkan kesamaan dan keselarasan tindakan serta persepsi dari aparat pelaksana kebijakan agar sesuai dengan ketentuan dan tujuan dari kebijakan tersebut. 
Menurut Edward III, ada tiga indikator yang dapat digunakan untuk mengkur keberhasilan variabel komunikasi, yakni terdiri dari : transmisi atau penyaluran komunikasi, kejelasan komunikasi serta konsistensi dari komunikasi yang dilakukan. Dikaitkan dengan implementasi program kampung $\mathrm{KB}$ berikut ini tabel yang akan menjelaskan secara singkat mengenai proses komunikasi yang dilakukan dalam implementasi program kampung $\mathrm{KB}$ di $\mathrm{RW} \quad 10$ Kelurahan Margadana:

Tabel 2. Rekapitulasi hasil wawancara mengenai proses komunikasi dalam implementasi program Kampung $\mathrm{KB}$ di RW 10 Kelurahan Margadana

\begin{tabular}{|c|c|c|}
\hline Indikator & $\begin{array}{l}\text { Implementasi } \\
\text { dalam Program } \\
\text { Kampung KB }\end{array}$ & Dampak \\
\hline $\begin{array}{l}\text { Media } \\
\text { Komunika } \\
\text { si }\end{array}$ & $\begin{array}{l}\text { Melalui rapat, } \\
\text { surat } \\
\text { pemberitahuan } \\
\text { dan laporan } \\
\text { pelaksanaan } \\
\text { kegiatan. } \\
\text { Komunikasi } \\
\text { antara } \\
\text { pelaksana } \\
\text { dengan akseptor } \\
\text { dilakukan } \\
\text { melalui } \\
\text { komunikasi } \\
\text { atau } \\
\text { pemberitahuan } \\
\text { secara langsung }\end{array}$ & $\begin{array}{l}\text { Memperjela } \\
\text { s tugas dan } \\
\text { fungsi } \\
\text { masing- } \\
\text { masing, } \\
\text { menciptakan } \\
\text { koordinasi } \\
\text { yang jelas } \\
\text { dan teratur. } \\
\text { Bagi peserta } \\
\text { akseptor KB } \\
\text { diadakan } \\
\text { sosialisasi } \\
\text { lebih lanjut }\end{array}$ \\
\hline $\begin{array}{l}\text { Kejelasan } \\
\text { Komunika } \\
\text { si }\end{array}$ & $\begin{array}{l}\text { komunikasi dari } \\
\text { pemerintah } \\
\text { setempat tidak } \\
\text { bisa } \\
\text { mempersatukan } \\
\text { dinas terkait } \\
\text { yaitu dinas } \\
\text { kependudukan } \\
\text { dan dinas } \\
\text { kesehatan }\end{array}$ & $\begin{array}{l}\text { koordinasi } \\
\text { yang } \\
\text { dilakukan } \\
\text { dalam } \\
\text { pelaksanaan } \\
\text { program } \\
\text { kampung } \\
\text { KB kurang } \\
\text { mengena. }\end{array}$ \\
\hline $\begin{array}{l}\text { Konsistens } \\
\text { i } \\
\text { Komunika } \\
\text { si }\end{array}$ & $\begin{array}{l}\text { Cukup } \\
\text { konsisten, tidak } \\
\text { terjadi } \\
\text { perubahan- }\end{array}$ & $\begin{array}{l}\text { Menciptaka } \\
\mathrm{n} \text { kesamaan } \\
\text { dan persepsi } \\
\text { dan }\end{array}$ \\
\hline
\end{tabular}

\begin{tabular}{ll} 
perubahan & pemahaman \\
aturan dan & di antara \\
petunjuk & pelasana \\
pelaksanaan & program \\
program & \\
kampung KB & \\
\hline
\end{tabular}

Dalam implementasi program Kampung KB, komunikasi yang dilakukan antar staf pelaksana kampung KB sudah cukup jelas dan kosisten dengan menggunakan beberapa transmisi atau media komunikasi seperti, melalui surat-surat edaran atau pemberitahuan resmi, rapat, pertemuan yang diikuti seluruh staf pelasana yang diselenggarakan secara rutin dalam kurun waktu tertentu di PLKB. Kegiatan yang dilakukan dalam pertemuan atau rapat tersebut meliputi pembahasan mengenai sosialisasi, pemberian arahan, penjelasan mengenai pelaksanaan program, serta pelaporan hasil pelaksanaan program Kampung KB di RW 10 Kelurahan Margadana. Dengan adanya komunikasi tersebut, aparat pelaksana dapat memahami tentang pedoman dan petunjuk pelaksanaan program kampung $\mathrm{KB}$ serta melaksanakan tugas dan fungsi yang harus dilakukan oleh masingmasing pihak.

Selanjutnya, komunikasi yang dilakukan antara petugas pelaksana dengan masyarakat sebagai target sasaran program kampung KB lebih cenderung berupa komunikasi atau pemberitahuan secara langsung tanpa dilakukan sosialisasi ataupun penyuluhan secara khusus. Proses yang dilakukan biasanya hanya berupa pemberitahuan program secara langsung kepada akseptor KB di RW 10 Kelurahan Margadana. 


\section{Disposisi dalam implementasi program Kampung KB}

Disposisi atau komitmen merupakan faktor yang berasal dari dalam diri pribadi setiap staf pelaksana program yang berupa kesediaan atau kemauan staf pelaksana untuk melaksanakan tugas dan kewajiban dalam pelaksanaan program dengan sebaik-baiknya sesuai dengan pedoman dan petunjuk yang telah ditetapkan. Apabila implementor memiliki disposisi yang baik, maka dia akan dapat menjalankan kebijakan dengan baik seperti apa yang diinginkan oleh pembuat kebijakan. Namun ketika implementor memiliki sikap atau perspektif yang berbeda dengan pembuat kebijakan, maka proses implementasi kebijakan juga menjadi tidak efektif (Subarsono, 2005).

Kesediaan dan kemauan para pelaksana ini dipengaruhi oleh tiga unsur sebagai berikut: pertama adalah kognisi (tingkat pengetahuan dan pemahaman) mereka akan kebijakan; kedua, arah respon mereka terhadap kebijakan; ketiga, intensitas respon mereka terhadap kebijakan tersebut. Jika ketiga hal tersebut menunjukkan arah positif makan tingkat kesediaan untuk melaksanakan kebijakan akan tinggi, dan begitu pula sebaliknya (Agustino, 2006).

Dikaitkan dengan implementasi program Kampung KB di RW 10 Kelurahan Margadana, berikut ini akan dijelaskan hasil rekapitulasi data mengenai disposisi pelaksana program
Kampung KB di RW10 Kelurahan Margadana :

Tabel 3. Rekapitulasi Hasil Pengumpulan Data mengenai Disposisi Pelaksana dalam Implementasi Program Kampung KB di RW 10 Kelurahan Margadana

\begin{tabular}{|c|c|c|}
\hline Indikator & $\begin{array}{l}\text { Implementasi } \\
\text { program } \\
\text { Kampung KB }\end{array}$ & Dampak \\
\hline $\begin{array}{l}\text { Pengetahuan } \\
\text { dan } \\
\text { pemahaman }\end{array}$ & $\begin{array}{l}\text { Staf pelaksana } \\
\text { memahami } \\
\text { maksud, tujuan } \\
\text { dan pelasanaan } \\
\text { program kampung } \\
\text { KB }\end{array}$ & $\begin{array}{l}\text { Menimbulkan } \\
\text { respon dan } \\
\text { dukungan } \\
\text { positif } \\
\text { pelaksanaan } \\
\text { programkampun } \\
\text { g KB }\end{array}$ \\
\hline $\begin{array}{l}\text { Komitmen } \\
\text { dan } \\
\text { pelaksana }\end{array}$ & $\begin{array}{l}\text { Memiliki } \\
\text { komitmen cukup } \\
\text { tinggi, patuh dan } \\
\text { bertanggung } \\
\text { jawab terhadap } \\
\text { tugas }\end{array}$ & $\begin{array}{l}\text { Pelaksanaan } \\
\text { program } \\
\text { kampung KB } \\
\text { dapat dilakukan } \\
\text { dengan } \\
\text { maksimal }\end{array}$ \\
\hline
\end{tabular}

Sumber : Hasil pengolahan data

Petugas pelaksana Kampung KB memiliki disposisi yang cukup tinggi yakni dilihat dariunsur pengetahuan dan pemahaman terhadap program kampung KB serta komitmen yang diberikan terhadap pelaksanaan program. Disposisi tersebut terwujud dengan adanya para pelaksana yang telah memiliki pengetahuan dan pemahaman yang jelas dan memadai mengenai isi, maksud serta tujuan dari implementasi program Kampung KB. Mereka memahami bahwa program ini merupakan program yang sangat efektif dalam membantu upaya pemerintah dalam meningkatkan kualitas penduduk melalui partisipasi keluarga, masyarakat, peran 
pemerintah,lembaga non pemerintah serta swasta dalam melasanakan program KKBPK. Banyaknya manfaat dari program kampung $\mathrm{KB}$ tersebut menimbulkan munculnya penilaian dan dukungan positif dari staf pelaksana terhadap pelaksanaan program Kampung KB. Munculnya dukungan tersebut juga dipengaruhi oleh pelaksanaan program Kampung KB di RW 10 Kelurahan Margadana yang sejauh ini berjalan cukup baik, lancar serta tidak ada kendala bagi para staf pelaksana program. Sikap penilaian positif ini yang kemudian mendorong tumbuhnya kesadaran serta komitmen dari para staf pelaksana tersebut untuk dapat melaksanakan fungsi dan tugas masing-masing, penuh dengan rasa kepatuhan dan tanggung jawab dalam memberikan pelayanan dalam program KB kepada masyarakat.

\section{Simpulan}

Implementasi

Program

Kampung KB di RW 10 Kelurahan Margadana :

1. Komunikasi pada pelaksanaan program Kampung KB yang terdiri dari beberapa indikator diantaranya yaitu, transmisi, kejelasan, dan konsistensi dalam pelaksanaan program Kampung KB di Kelurahan Margadana sudah berjalan dengan baik

2. Sumberdaya pada pelaksanaan program Kampung KB yang terdiri dari empat indikator yaitu, sumberdaya manusia (staf), informasi, wewenang, dan fasilitas dalam pelaksanaan program Kampung KB di Kelurahan Margadana RW 10 masih belum berjalan dengan baik, karena salah satu indikator sumberdaya yaitu fasilitas yang tersedia masih kurang memadai

3. Struktur Birokrasi dalam mendukung kinerja pelaksana program Kampung $\mathrm{KB}$ sudah terdapat SOP dan fragmentasi telah berjalan dengan baik dan efektif karena telah sesuai dengan peran dan tugas pelaksana dalam program ini

Dalam pelaksanaan program ini terdapat faktor penghambat dalam implementasi program Kampung KB diantaranya faktor internal yaitu kurangnya anggaran berupa dana yang diberikan oleh pemerintah terhadap pelaksanaan program Kampung KB, karena program tersebut belum mempunyai alokasi khusus dalam anggarannya. Sedangkan faktor eksternal yaitu kurangnya partisipasi serta kesadaran masyarakat yang masih belum ikut serta dalam pelaksanaan program Kampung KB di RW 10 Kelurahan Margadana.

Adapun saran yang dapat diberikan peneliti dalam implementasi program Kampung KB dalam upaya pencegahan 4T di Kelurahan Margadana RW 10 adalahbaiknya fasilitas seperti Posko Kampung KB dibuat khusus untuk kegiatan yang berkaitan dengan $\mathrm{KB}$ sehingga lebih memudahkan masyarakat dalam menyalurkan aspirasinya dan akan menjadi lebih efektif karena tidak akan menganggu pelayanan di kantor Kelurahan Margadana. Untuk mengatasi respon masyarakat yang masih rendah, pihak BKKBN selaku penanggung jawab dari program 
Kampung KB harus bisa menguatkan partisipasi masyarakat kepada masyarakat yang terlibat dalam program Kampung KB, serta lebih rutin melakukan sosialisasi langsung kepada masyarakat terkait pelayanan KB secara aktif.

\section{Daftar Pustaka}

Almatsier, S. (2009). Prinsip Dasar Ilmu Gizi. Jakarta : Penerbit PT Gramedia Pustaka Utama.

Asih \& Pratiwi. (2010). Perilaku Prososial ditinjau dari Empati dan Kematangan Emosi. Jurnal Psikologi, Volume I, No 1. Kudus: Universitas Muria Kudus.

Agustino, Leo. 2008. Dasar-dasar Kebijakan Publik. Bandung: Alfabeta.

Moleong, Lexy J. 2013. Metodologi Penelitian Kualitatif. Bandung: PT Remaja Rosdakarya.

Mulyadi, Deddy. 2016. Studi Kebijakan Publik dan Pelayanan Publik: Konsepdan Aplikasi Proses Kebijakan Publik Berbasis Analisis Bukti untuk Pelayanan Publik. Bandung: Alfabeta.

Suaib, Muhammad Ridha. 2016. Pengantar Kebijakan Publik: dari AdministrasiNegara, Kebijakan Publik,

\begin{tabular}{|c|c|c|}
\hline Administrasi & & Publik, \\
\hline Pelayanan & Publik, & Good \\
\hline $\begin{array}{l}\text { Governance, } \\
\text { Implementasi }\end{array}$ & & $\begin{array}{r}\text { hir } \\
\text { Kebijc }\end{array}$ \\
\hline ublik. Yo & & Calp \\
\hline
\end{tabular}

A. G Subarsono, 2005. Analisis Kebijakan Publik Konsep, Teori dan Aplikasi. Yogyakarta : Pustaka Pelajar.

Thoha, Miftah, 2013, kepemimpinan dalam manajemen, edisi $1, \mathrm{PT}$ RajaGrafindo, Jakarta 